\title{
19.-21. Yüzyıl İngilizce Yazan Yazarların Eserlerinde Bilişsel-Dilsel Açıdan Çiçek Kokularının İsimleri
}

\author{
The Names of Flower Scents in terms of Cognitive-Linguistics in the Works of \\ English-Speaking Writers in the $19^{\text {th }}-21^{\text {st }}$ centuries
}

\section{Deniza ZHAROVA*}

Özet: Bazı anlayış kullanımında yatan kültürler arasındaki farklılıklar biliş biliminin linguistik semantiği ve pragmatiğinin gelişmesine yeni ufukları açıyor. Biliş bilimi geniş kapsamlı olup anlayış, kavram, psikoloji, hatta bilgisayar ve yazılım alanında önemli rol oynamaktadır. Bu makalede sadece İngilizce yazan yazarların edebiyatında bazı bitkilerin isimlerinin kullanımı incelenmektedir. Ana araştırma çerçevesinde ise İngiliz, Fransız ve Rus dili edebiyatında her ayrı kültürde ilgili nesnelerin cazibesini belirleyen sebepleri tespit etmeye çalışılmaktadır. Seçim sonucunda İngilizcede en ünlü parfümlerin isimlerinde en sık kullanılan bitki isimlerin bulunduğu 6000 metin parçası tespit edilmiştir. Analiz için genellikle çiçek olan bitki isimlerinden bahseden tüm metin parçaları alınmıştır (çiçek aroması, çiçekle kıyaslama, çiçekten süs veya dekor olarak bahsedilmesi vs). Verilen örnekler bilişsel faaliyetin sonucunda bireyin dünya hakkında bildiği ve düşündüğü anlamlar sistemi oluştuğunu göstermektedir. Tecrübemiz, dünya ile ilgili saklanan ve alınan bilgiler, belirli kelime ve ifade kullanmamızda kendini gösterir.

Anahtar sözcükler: Biliş Bilimi, Biliş Dil Bilimi, Biliş Semantiği, Karşıtlık Dil Psikolojisi

Abstract: Inter-cultural differences between concept usage gives a new perspective for cognitive linguistic semantics and pragmatics. In cognitive science in general meaning plays an important part in psychology and in the field of computers and software. In this article the use of several flower names in Englishspeaking literature is analyzed. In our basic research we tried to find regularities and differences in the use of aromatic objects in English, French and Russian linguistic cultures. We analyzed about 6000 extracts containing the names of the flowers which are the most frequently employed in perfume-naming in English. We divided the extracts into several groups considering their general meaning (those are: flower scent, perfume, comparison with a flower or its part, the use of a flower as decoration or ornament etc.). These examples demonstrate that as the result of cognitive activity a concept system is created. This system relates to human knowledge and thoughts about the world. Our experience, received and retained information about the world appears in the word and phrase employed.

Keywords: Cognitive science, Cognitive Linguistics, Cognitive Semantics, Contrastive Linguistic Psychology

Biliş biliminin (cognitio-cognitive science-biliş, kavrama, algılama) araştırma konusu - insan aklındaki düşünme ve zihinsel süreçleri ve durumlarıdır. Bu bilim, insanın dünyayı algılama, öğrenme süreçlerini araştırmaktadır. Dikkatinize sunulan bu makalede biliş biliminin sadece linguistik dalında yer alan süreçlerine değiniyoruz. Biliş bilimi geniş kapsamlı olup anlayış, kavram, psikoloji, hatta bilgisayar ve yazılım alanında önemli rol oynamaktadır. "Bilişs süreç-

\footnotetext{
*PhD., Moskova Devlet Pedagoji Üniversitesi, Moskova, Rusya, denidelippa@gmail.com
} 
lerin mevcut, araştırılabilen ve büyük bir olasılıkla kavranabilen olduğunu uzun zamandır beklenen bilgisayarın icadı doğrulamıştır” (Neisser, 1981, 2).

Bilişsel faaliyetin sonucunda insanın dünya ile ilgili bildiği ve düşündüğü anlamlar sistemi oluşturulmaktadır. Bilişsel dilbilimin ilgi merkezinde 'bilginin kodlamasında ve aktarılmasında rol oynayan işaret sistemi olan bilişsel alet, genel bilişsel mekanizma olarak dil bulunmaktadır. Bu sistem, insanın diğer semiyotik aletlerden farklı olarak, kişiye bağlı olmadan oluşan ve birey oluşta benimsenmesi gereken aynı zamanda hem iç, hem de dış nesnesi olmaktadır' (Demyankov, \& Kubryakova, 1996, 53).

'... her algılayan organizmanın, çevrenin bazı yönlerini diğerlerinden daha çok farketme veya genel olarak herhangi bir şeyi farketme imkanı veren belirli yapıların olmak zorunda olduğu' (Neisser, 1981, 31) bilinmektedir. Bu yapılara bilişsel psikolojide şema adı verilir. Bu şemalar Neisser’e göre genel olarak (görsel, işitsel, dokunsal v.s.) algılamaya yöneliktir.

Bu makalede sadece İngilizce yazan yazarların edebiyatında bazı bitkilerin isimlerinin kullanımı incelenmektedir. Ana araştırma çerçevesinde ise İngiliz, Fransız ve Rus dili edebiyatında her ayrı kültürde ilgili nesnelerin cazibesini belirleyen sebepleri tespit etmeye çalışılmaktadır. Analiz için önceki çalışmada (Zharova, 2012) belirtildiği gibi ilgili kültürlerin parfüm isimlerinde en sık kullanılan bitki isimleri seçilmiştir. Dilbilimsel estetiğin bu bölümündeki analiz şeması genel olarak (Demyankov, 2004, 2011) çalışmalarında tanımlanmıştır. Araştırmamızın teori ve uygulama diye iki yönü vardır. Teori açısından ilgi alanımız cazip olan ile ilgili evrensel ve idyomatik ve etnik dil parametrelerinin belirlenmesidir. Uygulamalı dil bilimi için amacımız, nesnelerin isimlerinin kullanımının altında bulunan stereotip, şema ve çerçevelerin tespit edilmesidir. Bu stereotipler ve şemalar ana dil konuşanlara belirtilen nesnelere karşı yavaş yavaş estetik dahil olmak üzere belirli düşünceleri empoze etmektedir. Çeşitli kültürlerde edebi metinler, sanat v.b. imkan aracılı̆ğyla sadece belirli bir halkın stereotiplerini ifade etmekle kalmayıp bu stereotipleri okuyucu ve seyircilerinde geliştirmekte, yani canlandırmakta, yeniden üretmektedir. Adı geçen stereotipler ile ilgili bilgilere dayanarak bilerek, bilimsel esasa dayanarak parfümlerin yeni markaların isimleri bulunabilir ve yeni malların potansiyel cazibesi önceden kestirilebilir. Bu ampirik araştırmanın uygulama açısındaki anlamı bundan ibarettir.

Bu makalenin materyali olarak, 19.-21. yüzyılın önde gelen edebiyat uzmanlarının eserlerini yeterli ölçüde yansıtan birçok metinden alınan İngiliz dilindeki edebi eserleri seçmiştik.

Seçim sonucunda İngilizcede en ünlü parfümlerin isimlerinde en sık kullanılan bitki isimlerin bulunduğu 6000 metin parçası tespit edilmiştir. Bunlardan en sık kullanılan gül'dür ve genelin \%30.8 oluşturur, ardından zambak - \%21, menekşe - \%18 (menekşe rengi, mor anlamına gelen violet dahil olmak üzere 1000 üzerinde metinde) gelir. Daha sonra kullanma sıklığı azalarak sirasiyla eğreltiotu - \%10,3, yasemin ve leylak \%3,7'er her biri, lavanta - \%2,7, manolya $\% 2,6$, süsen - \%2,5, mimoza - \%2, vanilya, sümbül ve kamelya - \%0,6, gardenia - \%0,5 ve inci çiçeği - \%0,4 gelir.

Analiz için genellikle çiçek olan bitki isimlerinden bahseden tüm metin parçaları alınmıştır. Bunlar şunlardır:

1) Sadece bitki ismi, örneğin: She looked down at the bunch of violets she held, and touched the purple and white blossoms tenderly (Corelli, 1906);

2) Çiçek aroması, örneğin: I followed her upstairs and into a little room with a sloping ceiling and a window looking out upon the garden; and at the sight of the neat little place, smelling of lavender, and with some flowers in a jug upon the drawers, the depression which kept haunting me was driven away (Fenn, 1886); 
3) Çiçekle kıyaslama: She was a girl of seventeen, with blue eyes, auburn hair, and a complexion as fair as a lily (Cooke, 1936);

4) Çiçekten süs veya dekor olarak bahsedilmesi: They led me into the house where a delightful surprise awaited me, for the rooms had been decorated with balsam boughs and sweet ferns (Bacheller, 1917);

5) Sanatsal ifadesini arttırmak amaciyla kullanılan sıfat: "Oh, what a lovely bush of lilac!" And she hastened on a few steps in order to look more closely at the admired blossoms, which were swaying in the light breeze over the top of a thick green hedge - "Why, it must be growing in your garden! (Corelli, 1906);

6) Bitki isimlerin kullanıldığı idyomatik deyimler: We were in love-"we think"-and everything was coming up roses (McNab, 1996);

7) Bitkilerin bir şeyin sembolü olarak kullanıldığı metinler: Life is a composite of contradictions - a puzzle to the wisest of us: the lily lifting its graceful purity aloft may have its roots in a dunghill (Scott, 1921);

8) Bitki isimlerinin özel isim veya coğrafik isim olarak kullanıldığı metinler: One of my favorite things to do is to walk along Pleasant Street to Lily Lane, or through Vestal Street, just about dusk, and see the darling interiors of the spotless cottages (Comfort, 1912).

Gördüğümüz gibi tüm metinleri çiçeklerin olduğu ve çiçeklerin olmadığg ancak bir özelliğinin (rengi veya taçyapraklarının yumuşaklığı) olduğu iki gruba ayırabiliriz. Birinci türün örnekleri: The wide jaws closed upon it, its shrieks were stifled, and the next moment its silken body, along with the head of the anaconda, disappeared among the leaves of the mimosa (Reid, 2002). Çiçek özelliği söz konusuysa, sık sık bir şey veya kimse çiçekle kıyaslanmaktadır. Örneğin kadın sık sık çiçeğe, cildi ise taçyapraklarının yumuşaklığına benzetilir:

"I've never seen a woman blossom so".-"Yes, but she'll wither like a broken camellia when she's accused before Buntaro-san (Clavell, 2009).

Fascinated by her wonderful elfin look as she stood like a white iris in its silken sheath... ( Corelli, 1921).

Ancak sadece kadınlar değil, erkekler de çiçeklere benzetilir ama bu duruma çok daha seyrek rastlanılır:

Men are like roses and lilacs, which, too carefully cultivated to please the eye, lose something of their native fragrance (Grayson, 1917).

Uyandırılan hislere dayalı kıyaslamalar çok ilginçtir:

The touch of their heavenly bodies, he said, sent a sensation of roses and lilies through his earthly body; they refined him and attracted him upward, and he was sure he had sometimes risen a little way into the air (Adams, 1856).

No, it is not love, but a sacred ethereal kind of affection, resembling love only as the fragrance of violets resembles the taste of honey and the honey-comb (Hudson, 1904).

Belirtilen metin parçalarında sık sık sabit kıyaslamalar bulunabilir. Böylece güller genellikle muhteşem, harika, şahane olur:

What perfectly marvelous roses! (Kyne, 2007).

Do you love the queenly rose, and the modest lily of the valley, reader? (Cooke, 1936).

Leylak ise nostaljik eski moda metinlerinde sık sık kullanılır: 
Lilacs are old in soul, too, and their fragrance is loved untellably by many mystics, though the green of their foliage is questionable (Comfort, 1916).

Upon the side of it, along the town road, are two or three old farms with lilacs like trees about their doorways, and ancient apple orchards with great gnarly branches, and one has an old garden of hollyhocks, larkspurs, zinnias, mignonette, and I know not how many other oldfashioned flowers (Grayson, 1917).

Büyük kar beyazı manolya çiçeklerinin kullanılması da oldukça sıktır:

There, too, flourishes the giant reed, the fan-palm, and the broad-leafed magnolia, with its huge snow-white flowers. (Reid, 2013).

There are the white-flowered magnolias, at an elevation of from four thousand to eight thousand feet, which are then replaced by the still more gorgeous purple magnolia (Magnolia Campbellia) the latter being the most superb species known, its brilliant corollas often arraying the sloping sides of the hills as with a robe of purple (Reid, 2002).

In another quarter of an hour we were there, and, making the boat fast to a beautiful tree with broad, shining leaves, and flowers of the magnolia species, only they were rose-colored and not white, which hung over the water, we disembarked (Haggard, 1886).

Bitkilerin yüzyıllara göre kullanım dinamiğine bakalım.

19. yüzyılda yazarların eserlerinde aşağıdaki bitki tercihi cetvelimiz var:

Rose $(23 \%)>$ Jasmine $(15 \%)>$ Violet $(14.6 \%)>$ Lily $(14.2 \%)>$ Fern $(10 \%)>$ Magnolia $(8.5 \%)>$ Mimosa $(4.6 \%)>$ Lilac $(4 \%)>$ Vanilla $(1.7 \%)>$ Iris $(1.6 \%)>$ Lavender $(1.4 \%)>$ Lily of the valley $(0.6 \%)>$ Hyacinth $(0.4 \%)>$ Gardenia $(0.3 \%)>$ Camellia $(0.1 \%)$.

Robert Louis Stivenson'un eserlerinde gül ve leylak özellikle sık kullanılmaktadır. Yasemin en çok R. K. Duglas'ın eserlerinde bulunur. Diğer bitkilerin 19. yüzyıl yazarların eserlerinde kullanım sıklığı hemen hemen aynıdır.

19. yüzyıldan 20. yüzyıla geçiş dönemindeki yazarların eserlerinde benzer cetvel aşağıdaki gibidir:

Rose $(33.7 \%)>$ Lily $(20 \%)>$ Violet $(19.7 \%)>$ Fern $(11.2 \%)>$ Lilac $(3.8 \%)>$ Lavender $(2.6 \%)>\operatorname{Mimosa}(2 \%)>$ Iris (1.8 \%) > Jasmine, Magnolia $(1.7 \%)>$ Hyacinth $(0.6 \%)>$ Camellia $(0.5 \%)>$ Lilyofthevalley, Gardenia $(0.3 \%)>$ Vanilla $(0.1 \%)$.

Burada Maria Korelli’nin eserlerinde nilüfer özel isim olarak 94 defa kullanılmıştır.

20. yüzyıldan bu yana edebiyat alanında isimleri duyurulan yazarların benzer cetvel aşağıdaki gibidir: Lily $(32.3 \%)>$ Rose $(25 \%)>$ Violet $(13 \%)>$ Fern $(7 \%)>$ Iris $(6.3 \%)>$ Lavender (4.4\%) > Lilac (2.7 \%) > Jasmine, Vanilla (2 \%) > Camellia (1.3 \%) > Gardenia, Magnolia (1.2 \%) > Hyacinth (0.8 \%) > Mimosa, Lilyofthevalley (0.4\%).

Burada nilüfer en sık Clive Cussler'in eserlerinde, gül ise Ian Fleming'in Bondiana'sında kullanılır. Yazarların ikisi de diğerlerine göre daha sık menekşeyi kullandılar.

Gördüğümüz gibi gül adı 20. yüzyılının sonuna kadar lider durumdaydı, sonra nilüfer onun yerine geçti. Gül, menekşe ve yasemin gibi bitkilerin kullanımları arasında istatistiğe yansıyan özel isimlerin kullanımını belirtmek gerekmektedir.

Gelecek dönemlerde gülün pozisyonunda büyük puan düşmesinin olmayacağını tahmin edebiliriz, zira nilüfer ile olan fark büyük değildir. Nilüfer'in sıklık başarısı büyük bir olasılıkla Lily özel insan ismi olarak eski Rose ismine göre daha artmış olan kullanımına bağlıdır. Nilüfer ise durumunu sabitleştirecek, diğer bitkiler ise daha az kullanılacaktır: muhtemelen bu geleneksel hoş kokulu bitkilerin yerine diğer aromatik nesnelerin isimleri geçecektir. 
En önemli hedefimiz birçok algılama türünden sadece birinin yani adı bitki isimleriyle motive edilen kokuların çekiciliğinin sebeplerini tespit etmektir. Böyle kısa metinlerin, çiçeğin görsel görüntüsünden bahsedilenlere göre daha az olduğu ortaya çıtı. İngiliz edebiyatı metinlerinin ampirik araştırması, bitkilerin algılamasında görsel görüntünün ağır bastığını göstermektedir, yani özellikle görsel görüntü çoğu bitkinin aklımızdaki temsilci rolünü oynar. Aroma ise genellikle yardımcı bir rol oynar. Vanilya adı Rusça ve İngilizce'de istisnadır: bu kokuyu hepimiz biliriz, ama bitkinin nasıl göründüğünü herkes bilmez.

Çiçek kokuları genellikle hoştur, bizim materyallerimiz bunu doğruluyor:

Some of the sweetest flowering shrubs, such as the lilac, have the bitterest of leaves and twigs or, like certain kinds of clematis, have a seed that when green is sharper than cayenne pepper, while others, like the rose, are pleasanter in flavor (Grayson, 1917).

As they went they passed through a little stretch of woodland by the stream, where on this spring day the wild daffodils and lilies of the valley were abloom making sweet the air (Rider, 2009).

She remembered the spray of whitelilac he had given her, and fancied she could almost inhale again its delicious perfume (Corelli, 1906).

Görünen istisnalar bu kuralı doğrular, örneğin:

Big forced roses, - great lolling, sickly-scented lilies, and orchids - oh dear! (Corelli, 1906).

The paper on which it was written was thick and satiny, - and there was a faint artificial odour of violets about it which annoyed him (Corelli, 1906).

Pah!" - and Zabastes sniffed the air in disgust- "Thou hast a most vile odor of jessamine about thee! (Corelli, 1889).

Bu gibi cümlelerde çiçek aromasının değil (o eskisi gibi hoş), bu kokunun algılandığı, durumun geneli ile ilgili çağrışımların doğurduğu hoş olmayan hislerden bahsedilir.

İncelenen kısa metin parçalarında sık sık özel bir ortam oluşturan veya mevsimi simgeleyen bir şey olarak çiçek aromasından bahsedilir:

Some few days after the Duchess's dinner-party, Alwyn was strolling one morning through the Park, enjoying to the full the keen, fresh odors of the Spring, - odors that even in London cannot altogether lose their sweetness, so long as hyacinths and violets consent to bloom, and almond-trees to flower, beneath the too often unpropitious murkiness of city skies (Corelli, 1889).

A delicate, Spring-like odour floated to her as he came, and she saw that he carried a bunch of violets (Corelli, 1906).

Verilen örnekler bilişsel faaliyetin sonucunda bireyin dünya hakkında bildiği ve düşündüğü anlamlar sisteminin oluştuğunu göstermektedir. Tecrübemiz, dünya ile ilgili saklanan ve alınan bilgiler, belirli kelimeler ve ifadeler kullanışımızda kendini gösterir. Edebi metinlerde seçilmiş isimlerin kullanımını inceleyip bu realite ile ilgili bilgilere ait insan tecrübesini tarif ediyoruz. İnsanın bildiği ve düşündüğü şeylerin araştırılması insanın bilişsel faaliyetinin nasıl göründüğünü anlama imkanı sağlar. 


\section{KAYNAKÇA}

Adams, J. T. (1856). The Lost Hunter: A Tale of Early Times. New York: Derby and Jackson Company. Bacheller, I. (1917). The Light in the Clearing: A Tale of the North Country in the Time of Silas Wright. New York: Grosset and Dunlap Publishers.

Comfort, W. L. (1912). Fate Knocks at the Door. Philadelphia, London: J. B. Lippincott Company.

Comfort, W. L. (1916). Child and Country: A Book of the Younger Generation. New York: George H. Doran Company.

Corelli, M. (1906). God's Good Man: A Simple Love Story. New York: Dodd, Mead \& Company.

Corelli, M. (1921). The Secret Power. New York And Toronto: Doubleway, Page Company.

Corelli, M. (1889). Ardath: The Story of a Dead Self. London: Richard Bentley and Son Company.

Cooke, J. E. (1936). Mohun, or, The Last Days of Lee and His Palladins. Charlottesville, Va: Historical Publication Co. Inc.

Clavell, J. (2009). Shogun. BantamDell U.S.A.

Demyankov, V. Z. (2004). "Büyüleyici Güzellik”. Editör N. D. Arutyunova, \& M. Indriķ. Dilin Mantıksal Analizi: Estetik Dilleri: Güzellik ve Çirkinliğin Kavramsal Alanları, 169-208.

Demyankov, V. Z. (2011). "İtalyanca ve Rusça Güzellik Hakkında Notlar: Karşılaştırmalı Dilsel Estetik”. Filoloji Soruları, 1 (37), 60-63.

Demyankov, V. Z., \& Kubryakova, E. S. (1996) “Bilişsel Dilbilim”. Bilişsel Terimlerin Kısa Sözlüğü, 5355. Eds. E. S. Kubryakova, V. Z. Demyankov, Yu. G. Pankrats, \& L. G. Luzina. M: Lomonosov Moskova Devlet Üniversitesi Filoloji Fakültesi.

Grayson, D. (1917). Great Possessions. New York And Toronto: Doubleway, Page Company. Fenn, G. M. (1886) Brownsmith's Boy. London: Blackie and Son.

Haggard, R. H. (1886). She. Digireads.com Publishing.

Haggard, R. H. (2012). The Lady of Blossholme. The Floating Press.

Hudson, W. H. (1904). The Purple Land. New York: Random House, Publisher of the Modern Library.

Kyne, P. B. (2007). The Valley of the Giants. Dodo Press.

Manville, G. F. (1909). Brownsmith's Boy (A Romance in a Garden). United States: Indypublish Com.

Mcnab, A. (1996). Immediate Action. Printed in the USA, simultaneously in Canada: Dell Publishing.

Neisser, U. (1981). Biliş ve Gerçeklik-Bilişsel Psikolojinin Anlamı ve Prensipleri. Moskova:Progress, 232.

Reid, M. (2013). Popular Adventure Tales. Create Space Independent Publishing Platform.

Reid, M. (2002). The Plant Hunters: Adventures Among the Himalaya Mountains. Fredonia Books.

Scott, L. (1921). Children of the Whirlwind. Boston, New York: Houghton Mifflin Company.

Zharova, D. (2012). "Karşıllaştırmalı Onomastik Bilişsel Prensipleri (Rus ve Batı Avrupa dillerinde yapay koku adları)”. Bilişsel Dil Araştırmaları, XII, 579-584. Dil sunumunun Teorik Yönleri. Moskova: Dilbilim Enstitüsü: Tambov: G. R. Derzhavin Tambov Devlet Üniversitesi. 